\title{
Myrmica sabuleti (Hymenoptera: Formicidae) not necessary for the survival of the population of Phengaris (Maculinea) arion (Lepidoptera: Lycaenidae) in eastern Poland: Lower host-ant specificity or evidence for geographical variation of an endangered social parasite?
}

\author{
MARCIN SIELEZNIEW $^{1}$ and ANNA M. STANKIEWICZ ${ }^{2}$ \\ ${ }^{1}$ Department of Invertebrate Zoology, Institute of Biology, University of Bialystok, \\ Świerkowa 20B, PL-15-950 Białystok, Poland; e-mail: marcins@uwb.edu.pl \\ ${ }^{2}$ Laboratory of Social and Myrmecophilous Insects, Museum and Institute of Zoology, Polish Academy of Sciences, Wilcza 64, \\ PL-00-679 Warszawa, Poland; e-mail: ams@miiz.waw.pl
}

Key words. Lepidoptera, Lycaenidae, Phengaris arion, Maculinea, Myrmica rugulosa, Myrmica hellenica, Myrmica schencki, Myrmica sabuleti, myrmecophily, host specificity, social parasitism

\begin{abstract}
Larvae and pupae of the obligatorily myrmecophilous Phengaris (Maculinea) arion were found for the first time in nests of Myrmica rugulosa, M. hellenica and M. schencki at a site in eastern Poland. M. sabuleti, commonly considered as a major host of the butterfly and whose abundance is vital for the survival of $P$. arion populations, was shown to be very rare and not used. Estimated mean density of Myrmica nests was very low, which suggests that relatively vast areas are necessary to support a viable population of $P$. arion in similar sandy habitats. This may explain the decline and rarity of the butterfly in the whole region, even though its relationships with ants seem not to be very specific there.
\end{abstract}

\section{INTRODUCTION}

Caterpillars of the Large Blue Phengaris (Maculinea) arion (Linnaeus, 1758) (Lycaenidae) complete their development as social parasites of Myrmica ants. After the third (final) moult they leave the larval food plant (Thymus spp. or Origanum vulgare, depending on locality) and are then transported by Myrmica workers to their nests where they prey upon the host brood. These relationships are considered not only as obligatory for the butterfly but also as specific i.e. a single species of $\mathrm{Myr}$ mica is much more tolerant of caterpillars than other species. However, detailed studies on $P$. arion have in fact only been carried out at four sites in Britain, France and Sweden (Thomas et al., 1989; Elmes et al., 1998). They showed that over ninety percent of butterflies emerged from nests of M. sabuleti Meinert, 1861 and of the other Myrmica species present, only M. scabrinodis Nylander, 1846 was successfully exploited as a minor host. A significant difference in the survival rate of $P$. arion larvae among ant species was the most important biological factor in the butterfly's decline in Britain. The more thermophilous $M$. sabuleti was replaced by the less demanding M. scabrinodis when vegetation increased in height at abandoned sites (Thomas, 1980). Nevertheless secondary host nests may play an important role for population persistence in seasons with extreme events e.g. droughts (Thomas et al., 2005). Additionally Thomas \& Wardlaw (1990) found that colony structure might affect survival, i.e. mortality of $P$. arion caterpillars in $M$. sabuleti nests is higher when queen ants are present.
The complex life history of the Large Blue has triggered enormous scientific and conservational interest in the whole genus Phengaris Doherty, 1891 (Thomas \& Settele, 2004; Settele et al., 2005), which, according to Fric et al. (2007), is the senior synonym of Maculinea Van Eecke, 1915. However, the host-ant relationships of $P$. arion on a larger geographical scale have remained, surprisingly, the least known of all European Phengaris taxa (Pech et al., 2007). The first pupa of P. arion in Central and Eastern Europe was found in a M. lobicornis nest in Poland (Sielezniew et al., 2003). This anecdotal record indicated the importance of further studies in this region in order to obtain a better understanding of the ecological complexity of this species, which is endangered in many European countries (van Swaay \& Warren, 1999). Here we present further data from Poland, which for the first time indisputably prove that at least locally the butterfly does not depend on the "classic" host, M. sabuleti.

\section{MATERIAL AND METHODS}

Our studies were carried out near Tykocin $\left(53^{\circ} 13^{\prime} \mathrm{N} / 22^{\circ} 45^{\prime} \mathrm{E}\right.$, about $105 \mathrm{~m}$ a.s.l.) in the Valley of the Narew River, Podlaskie Voivodship, North-Eastern Poland. The whole site encompasses about 8 ha of open sandy land covered sparsely and almost exclusively by Juniperus communis bushes and cut through by a secondary road planted with Populus balsamifera trees. Borders are generally clear i.e. pine forest, arable land, wetter places (covered with Vaccinium vitis-idaea and Calluna vulgaris) and a small river separating the rest from intensive pasture.

The main habitat of $P$. arion (Fig. 1) and the study area (about 2 ha) is limited to more sheltered parts of the site and is confined to an area with the larval food plant Thymus serpyllum (about 15\% coverage of open ground) where imagines of the 


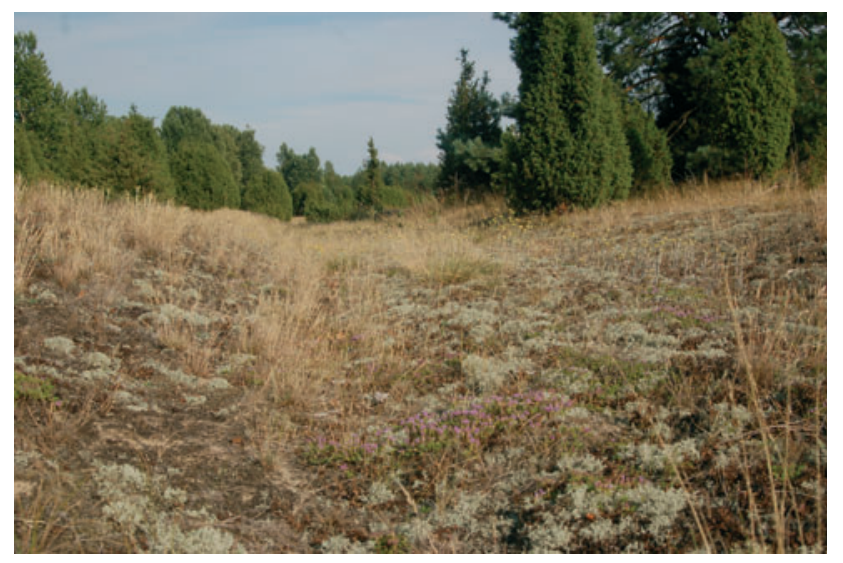

Fig. 1. Typical habitat of Phengaris arion at the site near Tykocin (NE Poland).

butterfly were regularly encountered. The type of vegetation can be classified as plant communities of All. Corynephorion canescentis (Ass. Spergulo vernalis-Corynephoretum). Patches of bare ground are very numerous and often quite extensive. Except for tussocks of grasses (mainly Corynephorus canescens) and herbs like T. serpyllum, Helichrysum arenarium, Scleranthus perennis, Sedum acre and Spergula morisonii, lichens also form a very characteristic component of the turf. The site is part of a local pasture commonwealth, but the land inhabited by $P$. arion is only rarely grazed by cattle because of its low productivity. Fires and local sand digging are much more important disturbances.

The flight period of $P$. arion on the site near Tykocin is typical for the region and lasts up to about six weeks from mid June to late July. The highest numbers of individuals are usually on the wing in early July when at least a dozen or so individuals might be observed daily. The relative abundance of the butterfly as well as the extent of the habitat compared to other sites in the region was one of the most important reasons for the selection of the study area.

Myrmica nests were examined in the first half of June or last days of May to maximize the chances of finding full-grown larvae or pupae (which develop in about three weeks), which is important in determination of host ant specificity of Phengaris butterflies (Thomas et al., 1989). Areas of turf were carefully inspected within $2 \mathrm{~m}$ of Thymus plants in patches where ovipositing females were most frequently observed. Occasionally we used sugar cubes as bait to attract workers and therefore to facilitate localisation of their colonies. The Myrmica nests located were excavated and checked for presence/absence of $P$. arion individuals. Voucher samples of 5-10 workers were collected. Studies were performed in 2003-2007 and every year just 1-3 days were dedicated to examination of the nests to minimise the possible negative effects of our activities. Addi-

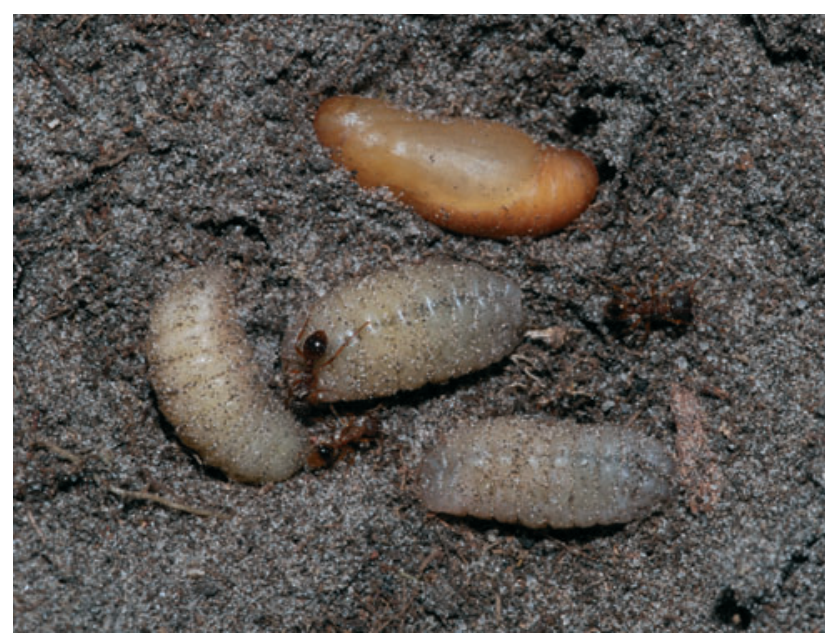

Fig. 2. Four individuals of Phengaris arion found in a single colony of Myrmica rugulosa at the site near Tykocin (NE Poland).

tionally, to estimate the average density of Myrmica colonies, 270 randomly chosen squares $\left(1 \mathrm{~m}^{2}\right.$ each) were surveyed in 2007. We also collected representatives of other ant genera to obtain non quantitative data on general species composition. All ants were identified in the laboratory using Czechowski et al. (2002).

\section{RESULTS}

During the five years of this study a total number of 58 colonies (6-16 every year) were excavated. They belonged to five species of Myrmica i.e. M. schencki Emery 1895, (22 nests), M. rugulosa Nylander, 1849 (15), M. hellenica Finzi, 1926 (17), M. sabuleti (3) and M. scabrinodis (1). We found 15 individuals of $P$. arion: 4 pupae, 9 full-grown larvae and 2 medium-sized larvae in chambers up to about $10 \mathrm{~cm}$ below ground level (Table 1). The highest number of individuals was recorded in 2007 from a $M$. rugulosa nest where one pupa, one prepupa and two caterpillars were found (Fig. 2.). M. rugulosa was also the most often infested Myrmica species (27\% colonies with $P$. arion) compared to $M$. hellenica $(18 \%)$ and $M$. schencki (9\%). However, Fisher's Test showed no significant differences in these proportions.

The average density of Myrmica nests turned out to be very low i.e. about 0.07 per $1 \mathrm{~m}^{2}$. Colonies were hidden in the turf, without solaria and therefore very difficult to find. M. rugulosa and $M$. hellenica nested often under Thymus plants, while entrances to M. schencki nests, with

TABLE 1. The number of Myrmica nests examined and their recorded use by $P$. arion at the site near Tykocin (NE Poland).

\begin{tabular}{lccccc}
\hline $\begin{array}{l}\text { Myrmica } \\
\text { ant species }\end{array}$ & Sample size & $\begin{array}{c}\text { Percent of all } \\
\text { Myrmica } \text { nests }\end{array}$ & $\begin{array}{c}\text { Number of nests } \\
\text { with } \text { P. arion }\end{array}$ & $\begin{array}{c}\text { Number of } \text {. arion in infected nests } \\
\text { (number of pupae and full-grown larvae) }\end{array}$ & $\begin{array}{c}\text { Percent of nests } \\
\text { with } P \text {. arion }\end{array}$ \\
\hline M. rugulosa & 15 & 26 & 4 & $8(7): 1(0), 1(1), 2(2), 4(4)$ & 27 \\
M. hellenica & 17 & 29 & 3 & $5(4): 1(1), 2(2), 2(1)$ & 18 \\
M. schencki & 22 & 38 & 2 & $2(2): 1(1), 1(1)$ & 9 \\
M. sabuleti & 3 & 5 & 0 & 0 & 0 \\
M. scabrinodis & 1 & 2 & 0 & 0 & 0 \\
\hline Total & 58 & 100 & 9 & $15(13)$ & 16 \\
\hline
\end{tabular}


characteristic chimneys, were usually in patches of bare ground in much more dense soil close to junipers.

Other ants collected at the site were: Formica cinerea Mayr, 1853, F. cunicularia Latreille, 1798, F. fusca Linnaeus, $1758, F$. pratensis Retzius, 1783, F. rufibarbis Fabricius, 1793, F. truncorum Fabricius, 1804, Lasius niger (Linnaeus, 1758), L. alienus (Förster, 1850), L. flavus (Fabricius, 1782), Solenopsis fugax (Latreille, 1798) and Tetramorium caespitum (Linnaeus, 1758).

\section{DISCUSSION}

M. rugulosa, M. hellenica and M. schencki are not recorded as hosts of $P$. arion. All of them are thermophilous ant species preferring generally drier and less grassy habitats compared to $M$. sabuleti and M. scabrinodis (Czechowski et al., 2002). M. rugulosa and M. hellenica are not recorded until now from $P$. arion sites (Thomas et al., 1989; Pauler-Fürste et al., 1996; Elmes et al., 1998; Sielezniew et al., 2003). For M. hellenica this is also the first record of participation in any butterfly-ant relationship (Fiedler, 2006). Two other $P$. arion hosts recorded from Tykocin were already observed supporting another xerothermophilous Phengaris butterfly - "P. rebeli", which recently was judged not a good species but only a subspecies or race of $M$. alcon (Als et al., 2004; Pecsenye et al., 2007; Fric et al., 2007). M. schencki is the main host of " $P$. rebeli" in western Europe (Thomas et al., 1989) and Lithuania (Stankiewicz et al., 2005b) and there is also a single record of a M. rugulosa colony infested from Poland (Stankiewicz et al., 2005a).

Studies on the host ant specificity of this butterfly in Poland appear to be by far the most time-consuming and laborious in comparison to studies of all other Phengaris taxa in the country (Stankiewicz \& Sielezniew, 2002; Steiner et al., 2003; Sielezniew \& Stankiewicz, 2004). Our results do not indicate the best host ant of $P$. arion at the site and we also have no information about the survival rate there of caterpillars in nests of particular $\mathrm{Myr}$ mica species. Moreover caterpillars of $P$. arion may exploit more than one Myrmica colony before pupation and even a change of species is possible. Ants often desert their nest after the brood has been eaten but $P$. arion has some ability to persist until the vacated nest is colonized again and fresh grubs become available (Thomas et al., 2005).

However, according to Thomas (1995) a minimum of $51 \%$ co-occurrence of $M$. sabuleti and the host plant is necessary for survival of a $P$. arion population (intrinsic growth rate $=1)$. Hence it is rather improbable that the "classic" host-ant of the butterfly, M. sabuleti, supports the $P$. arion population at the investigated site. Nevertheless, it is also impossible to judge the potential importance of $M$. sabuleti for the population as only three nests were found. In Poland this ant prefers warm grasslands and it is rather rare in very sandy places with extensive patches of bare ground. The type of vegetation at the Tykocin site is quite typical for eastern Poland (Sielezniew et al., 2005) and therefore we hypothesise that the presence of $M$. sabuleti is not vital for the survival of many $P$. arion populations in the region. However at the moment we are not able to state whether this is a result of lower specificity or geographical variation observed e.g. for $P$. alcon and " $P$. rebeli" (Elmes et al., 1994; Steiner et al., 2003; Stankiewicz et al., 2005b). The potential role of M. rugulosa, M. hellenica and $M$. schencki as hosts of $P$. arion populations studied by Thomas et al. (1989) and Elmes et al. (1998) is unknown because these ant species were not recorded at the study.

Perhaps $P$. arion is less specific towards the centre of its distribution area and apart from the M. sabuleti "race" there is another "continental" one. Data on the other predatory Phengaris species, P. teleius, suggests a similar pattern. Considered as specific to M. scabrinodis in France (Thomas et al., 1989), it turned out to be more of a generalist in Poland, Hungary and Romania, observed altogether with six Myrmica species (Stankiewicz \& Sielezniew, 2002; Witek et al., 2005; Tartally \& Varga, 2008). In Mongolia Woyciechowski et al. (2006) found pupae of $P$. teleius in nests of a further three hosts at sites where overall Myrmica species composition was completely different from that in Europe. Authors suggested that P. teleius is the least specific parasite among Phengaris, which may explain its wide distribution in the Palearctic.

$P$. arion is not less widespread, and therefore it is very likely that in the east other hosts are also used. $M$. sabuleti was also not suspected to be a host of $P$. arion in Finland, where $M$. lonae instead of $M$. sabuleti was exclusively recorded in the habitat of the butterfly (Kolev, 1998).

Als et al. (2004), considering the results of genetic analyses, suggest the possibility of the existence of further cryptic species among $P$. arion populations. It would be valuable to check whether those differences overlap with variation in host-ant specificity even though molecular studies did not reveal such a pattern for $P$. alcon and $P$. "rebeli". The ability to simultaneously exploit more than one Myrmica species does not preclude the existence of host races. For example caterpillars from Polish populations of $P$. alcon and $P$. "rebeli" in captivity develop successfully both in nests of $M$. sabuleti and M. scabrinodis, but with other ants mortality is very high (Sielezniew \& Stankiewicz, 2007).

The mean density of Myrmica ant nests recorded at Tykocin (700 nests/ha) is very low compared to $P$. arion habitats in Western Europe. On a British site with a breeding habitat considered as suitable but poor there were 6800 nests of the host-ant (M. sabuleti) per hectare (Mouquet et al., 2005). In south west Germany the mean nest density of M. sabuleti on P. arion sites was 2900 nests/ha. According to the modelling of population viability, if that parameter drops to about 500 nests/ha the extinction probability rises to 1 (Pauler-Fürste et al., 1996). At Tykocin the mean density of the most common Myrmica ant (M. schencki) was estimated at 250 nests/ha and the density of $M$. rugulosa (the most often infested species) at less than 200 nests/ha. Perhaps $P$. arion would 
not able to thrive in these relatively unsuitable conditions using a single host.

The low density of host nests in relation to the abundance of the larval food plant also means that many eggs of $P$. arion are laid far from colonies. According to Elmes et al. (1998) Myrmica workers only forage over a radius of about $2 \mathrm{~m}$ from their nests. Some preliminary observations suggest that this foraging zone is much larger in sandy habitats with extensive patches of bare ground. It may explain the relatively high incidence of caterpillars in Myrmica nests at Tykocin (1.7 per infested nest) comparable to data from Britain (Thomas \& Wardlaw, 1992).

However even effective exploitation of scarce resources cannot overcome species vulnerability in the case of restricted area. Therefore $P$. arion is a rather rarely encountered species even in habitats that appear suitable, in contrast to other Phengaris species in Poland. Our data show that it probably results from low mean density of Myrmica ant nests and the lower capacity of individual colonies to support developing butterflies. The recorded mean number of $P$. arion prematures is lower than that for other predacious Phengaris species i.e. P. teleius and $P$. naustithous studied in Poland (Stankiewicz \& Sielezniew, 2002). For P. alcon and P. "rebeli" (Steiner et al., 2003; Sielezniew \& Stankiewicz, 2004) mean numbers per nest are even much higher but this is mainly the result of a more effective "cuckoo" feeding strategy for exploiting of ant colonies (Thomas \& Elmes, 1998).

Habitat demands of $P$. arion and its major host ant vary according to regional climate (Thomas et al., 1998). However, until now only the requirements of the 'classic' host M. sabuleti were considered. Our data strongly suggest that an understanding of $P$. arion ecology is much more puzzling in Eastern Europe and probably also in other parts of its distribution in the Palaearctic.

ACKNOWLEDGEMENTS. This work was supported by the Ministry of Science and Higher Education (grant no. 2 P04G 024 30). M. Sielezniew would like to thank I. Dziekańska for help with the field studies in 2007 as well as A. Matusiewicz, M. Markiewicz, M. Bystrowska and C. Bystrowski for their support during his stay at Tykocin. Three anonymous referees made valuable comments on the manuscript.

\section{REFERENCES}

Als T.D., Vila R., Kandul N., Nash D.R., Hsu Yen, Mignault A., Boomsma J.J. \& Pierce N.E. 2004: The evolution of alternative parasitic life histories in large blue butterflies. Nature 432: 386-390.

Czechowski W., Radchenko A. \& Czechowska W. 2002: The Ants (Hymenoptera, Formicidae) of Poland. Museum and Institute of Zoology PAS, Warsaw, $200 \mathrm{pp}$.

Elmes G.W., Thomas J.A., Hammarstedt O., Munguira M.L., Martin J. \& van der MAde J.G. 1994: Differences in hostants specificity between Spanish, Dutch and Swedish populations of the endangered butterfly Maculinea alcon (Denis et Schiff.) (Lepidoptera). Memor. Zool. 48: 55-68.

Elmes G.W., Thomas J.A., Wardlaw J.C., Hochberg M.E., Clarke R.T. \& Simcox D.J. 1998: The ecology of Myrmica ants in relation to the conservation of Maculinea butterflies. $J$. Insect Cons. 2: 67-78.
FIEDLER K. 2006: Ant-associates of Palaearctic lycaenid butterfly larvae (Hymenoptera: Formicidae; Lepidoptera: Lycaenidae) - a review. Myrmecol. Nachr. 9: 77-87.

Fric Z., Wahlberg N., Pech P. \& ZrzavÝ J. 2007: Phylogeny and classification of the Phengaris-Maculinea clade (Lepidoptera: Lycaenidae): total evidence and phylogenetic species concepts. Syst. Entomol. 32: 558-567.

Kolev Z. 1998: Maculinea arion (L.) in Finland - distribution, state of knowledge and conservation. J. Insect Cons. 2: 91-93.

Mouquet N., Thomas J.A., Elmes G.W., Clarke R.T. \& Hochberg M.E. 2005: Population dynamics and conservation of a specialized predator: a case study of Maculinea arion. Ecol. Monogr. 75: 525-542.

Pauler-Fürste R., Kaule G. \& Settele J. 1996: Aspects of the population vulnerability of the large blue butterfly, Glaucopsyche (Maculinea) arion, in south-west Germany. In Settele J., Margules C., Poschlod P. \& Henle K. (eds): Species Survival in Fragmented Landscapes. Kluwer, Dordrecht, pp. 275-281.

Pech P., Fric Z. \& KonvičKa M. 2007: Species-specificity of the Phengaris (Maculinea) - Myrmica host system: Fact or myth? (Lepidoptera: Lycaenidae; Hymenoptera: Formicidae) Sociobiology 50: 983-1004.

Pecsenye K., Bereczki J., Tihanyi B., Toth A., Peregovits L. \& VARGA Z. 2007: Genetic differentiation among the Maculinea species (Lepidoptera: Lycaenidae) in eastern Central Europe. Biol. J. Linn. Soc. 91: 11-21.

Settele J., Kühn E. \& Thomas J.A. 2005: Studies on the Ecology and Conservation of Butterflies in Europe. Vol. 2: Species Ecology Along a European Gradient: Maculinea Butterflies as a Model. Pensoft Publishers, Sofia-Moscow, 289 pp.

Sielezniew M. \& Stankiewicz A.M. 2004: Simultaneous exploitation of Myrmica vandeli and M. scabrinodis (Hymenoptera: Formicidae) colonies by the endangered myrmecophilous butterfly Maculinea alcon (Lepidoptera: Lycaenidae). Eur. J. Entomol. 101: 693-696.

Sielezniew M. \& Stankiewicz A.M. 2007: Differences in the development of the closely related myrmecophilous butterflies Maculinea alcon and $M$. rebeli (Lepidoptera: Lycaenidae). Eur. J. Entomol. 104: 433-444.

Sielezniew M., Buszko J. \& Stankiewicz A.M. 2005: Maculinea arion in Poland: distribution, ecology and prospects of conservation. In Settele J., Kühn E. \& Thomas J.A. (eds): Studies on the Ecology and Conservation of Butterflies in Europe. Vol. 2: Species Ecology Along a European Gradient: Maculinea Butterflies as a Model. Pensoft Publishers, Sofia-Moscow, pp. 231-233.

Sielezniew M., Stankiewicz A. \& Bystrowski C. 2003: First observation of one Maculinea arion pupa in a Myrmica lobicornis nest in Poland. Nota Lepid. 25: 249-250.

Stankiewicz A. \& Sielezniew M. 2002: Host specificity of Maculinea teleius Bgstr. and M. nausithous Bgstr. (Lepidoptera: Lycaenidae) the new insight. Ann. Zool. 53: 403-409.

Stankiewicz A.M., Sielezniew M. \& Barański M. 2005a: The first record of Myrmica rugulosa Nylander, 1849 (Hymenoptera: Formicidae) as a host-ant of Maculinea rebeli Hirschke, 1904 (Lepidoptera: Lycaenidae). Pol. J. Entomol. 74: 99-103.

Stankiewicz A.M., Sielezniew M. \& Švitra G. 2005b: Myrmica schencki rears Maculinea rebeli in Lithuania: new evidence for geographical variation of host-ant specificity of an endangered butterfly. Myrmecol. Nachr. 7: 51-54.

Steiner F.M., Sielezniew M., Schlick-STeiner B.C., Höttinger H., Stankiewicz A. \& Górnicki A. 2003: Host specificity 
revisited: New data on Myrmica host ants of the lycaenid butterfly Maculinea rebeli. J. Insect Cons. 7: 1-6.

Tartally A. \& Varga Z. 2008: Host ant use of Maculinea teleius in the Carpathian Basin (Lepidoptera: Lycaenidae). Acta Zool. Acad. Sci. Hung. 54: (in press).

Thомаs J.A. 1980: Why did the large blue become extinct in Britain? Oryx 15: 243-247.

Thomas J.A. 1995: The ecology and conservation of Maculinea arion and other European species of large blue butterfly. In Pullin A.S. (ed.): Ecology and Conservation of Butterflies. Chapman \& Hall, London, pp. 180-197.

Thomas J.A. \& Elmes G.W. 1998: Higher productivity at the cost of increased host-specificity when Maculinea butterfly larvae exploit ant colonies through trophallaxis rather than by predation. Ecol. Entomol. 23: 457-464.

Thomas J.A. \& Settele J. 2004: Butterfly mimics of ants. Nature 432: 283-284.

Thomas J.A. \& Wardlaw J.C. 1990: The effect of queen ants on the survival of Maculinea arion larvae in Myrmica ant nest. Oecologia 85: 87-91.

Thomas J.A. \& Wardlaw J.C. 1992: The capacity of a Myrmica ant nest to support a predacious species of Maculinea butterfly. Oecologia 91: 101-109.

Thomas J.A., Elmes G.W., Wardlaw J.C. \& Woyciechowski M. 1989: Host specificity among Maculinea butterflies in Myrmica ant nests. Oecologia 79: 425-457.

Thomas J.A., Simcox D.J, Wardlaw J.C., Elmes G.W., HochBerg M.E. \& Clarke R.T. 1998: Effects of latitude, altitude and climate on the habitat and conservation of the endan- gered butterfly Maculinea arion and its Myrmica ant hosts. $J$. Insect Cons. 2: 39-46.

Thomas J.A., Elmes G.W., Schonrogge K., Simcox D.J. \& SetTELE J. 2005: Primary hosts, secondary hosts and "non-hosts": common confusion in the interpretation of host specificity in Maculinea butterflies and other social parasites of ants. In Settele J., Kühn E. \& Thomas J.A. (eds): Studies on the Ecology and Conservation of Butterflies in Europe. Vol. 2: Species Ecology Along a European Gradient: Maculinea Butterflies as a Model. Pensoft Publishers, Sofia-Moscow, pp. 99-104.

Van SwaAy C.A.M. \& Warren M.S. 1999: Red Data Book of European Butterflies (Rhopalocera). Nature and Environment, No. 99. Council of Europe Publishing, Strasbourg, 260 pp.

Witek M., Nowicki P., Skórka P., Sliwinska E. \& WOYCIECHOWSKI M. 2005: Host ant specificity and integration rate with Myrmica ants in larvae of Maculinea teleius butterflies. In Settele J., Kühn E. \& Thomas J.A. (eds): Studies on the Ecology and Conservation of Butterflies in Europe. Vol. 2: Species Ecology Along a European Gradient: Maculinea Butterflies as a Model. Pensoft Publishers, Sofia-Moscow, pp. 105-106.

Woyciechowski M., Slowik J. \& Muehlenberg M. 2006: Hosts of the butterfly, Maculinea teleius, among Myrmica ant in Northern Mongolia (Lepidoptera: Lycaenidae; Hymenoptera: Formicidae). Sociobiology 48: 493-502.

Received February 19, 2008; revised and accepted May 12, 2008 